\title{
耳下腺神経鞘腫の一症例と本邦報告例の検討
}

$\begin{array}{llll}\text { 渡 邊 } & \text { 睦・相川 } & \text { 通・岡村 } & \text { 洋沖 } \\ \text { 大谷 } & \text { 嚴・本田 } & \text { 学*.三沢 } & \text { 敬典* }\end{array}$

\section{Neurinoma in the Parotid Gland; A Case Report and Statistical Review of the Japanese Literature}

\author{
Mutsumi Watanabe, Tohru Aikawa, Hiro-oki Okamura and Iwao Ohtani \\ (Fukushima Medical Collage)
Manabu Honda and Takanori Misawa
(Ohta General Hospital)

\begin{abstract}
A case of neurinoma located in the right parotid gland is reported. The patient was a 62-year-old Japanese woman complaining of a painless lump in the right parotid gland region. Clinical examination revealed a tumor mass in the deep lobe of the right parotid gland. Facial nerve function was normal. The tumor was extirpated and did not show any apparent connection with the facial nerve. Histopathological examination revealed neurinoma. Thirty-one cases of neurinoma in the parotid gland have been reported in the Japanese literature. These cases as well as the present case are reviewed.
\end{abstract}

Key words: neurinoma, parotid gland, statistical observation

はじめに

耳下腺に発生する腫瘍は病理組織学的に多彩 である。その中でも，非上皮性腫瘍に属する神 経鞘腫は，本邦では米倉の報告1)以来 30 数例の 報告が見られるにすぎない比較的まれな腫瘍で ある.今回われわれは, 耳下腺神経鞘腫の一症 例を経験したので，これまでの本邦報告例につ いて併せて検討し報告する。

\section{症例}

症 例: 62歳, 女性.

主 訴: 右耳下腺部腫脹.

既往歴：30歳代上り右慢性中耳炎.
家族歴：特記すべきことなし.

現病歴：昭和63年 4 月頃より, 右耳下腺部腫 脹が出現し近医を受診した。腫脹が改善しない ため，同年12月 2 日太田綜合病院耳鼻咽喉科を 受診した.

初診時局所所見：右耳下腺部に $45 \mathrm{~mm} \times 50$ $\mathrm{mm}$ の腫瘍が認められた. 表面は平滑, 弾性硬 で圧痛はなく, 境界明膫で可動性があり, 皮虐 との癒着は認められなかった。耳鏡所見にて右 鼓膜に穿孔を認めたが，鼻咽喉頭には異常所見 は認められなかった。 顔面神経麻㽻はなく, 頸 部リンパ節も触知しなかった。

福島県立医科大学耳鼻咽喉科学教室（主任：大谷 嗾教授）

* 太田綜合病院耳鼻咽喉科 
検査所見：Sialo CT 軸位断で右耳下腺深葉 部に境界明膫で円形の腫瘍陰影を認めた（図 1 ). 内部性状の鑑別はできなかった，Gaシン チでは異常な集積は見られなかった。以上の諸

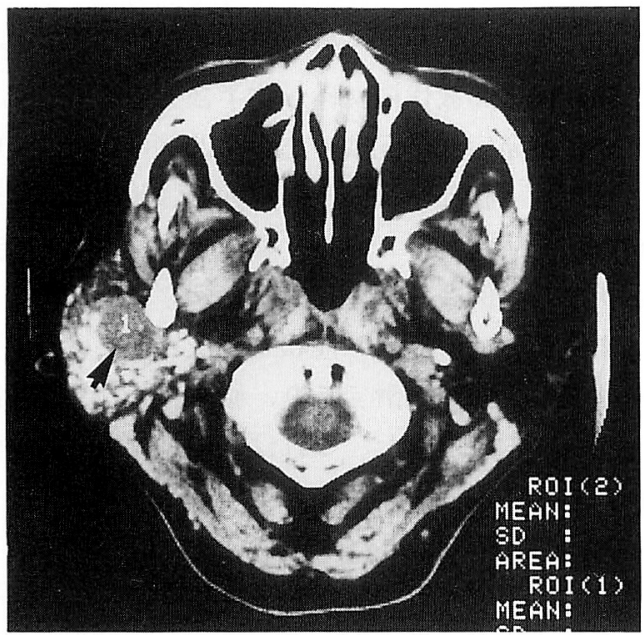

図 1 Sialo CT 軸位断

右耳下腺深葉部に境界明瞭で円形の腫瘍陰影（矢 印）が認められる.

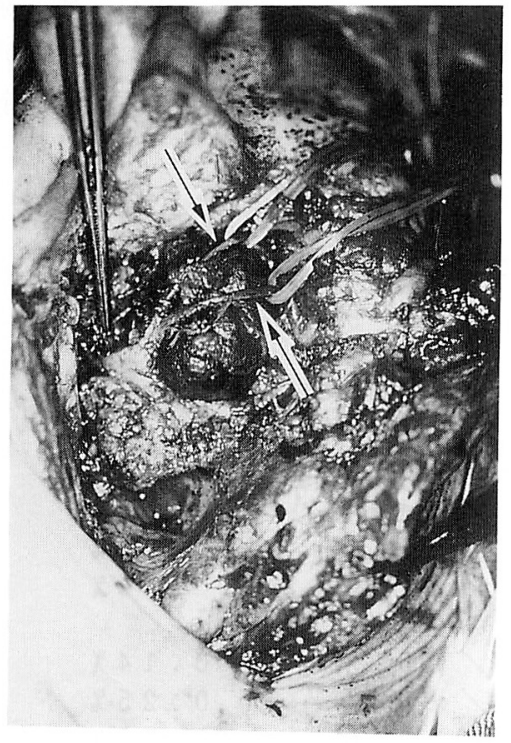

図 2 術中所見

腫瘍とその表面を走行する顔面神経（矢印）が認 められる。
検査より耳下腺深葉に発生した良性腫瘍と診断, 手術を勧めたが，本人の同意を得るまでに約 10 カ月外来にて経過を観察した。この間腫瘍に変 化はなかった，平成元年10月25日，全身麻酔下 に右耳下腺腫瘍摘出術を施行した。

手術所見：皮切は右側耳前部より下顎後方を 通り側頸部に達する逆 S 字状切開とした。顔面 神経を確認しつつ耳下腺浅葉組織を剥離すると， 顔面神経分岐部の下に被膜を有するくるみ大の 球形の腫瘍を認めた（図 2 )。腫瘍は囊胞様に 弾力に富久, 術中迅速病理検査のために被膜の 一部を切開すると，内部上り血性の内溶液の流 出がみられた。病理検査の結果は神経鞘腫と診 断された，顔面神経は伸展し，腫瘍を放射状に 取り巻く様に走行していたが腫瘍と顔面神経の 間には明らかな癒着はなかった。神経を慎重に 腫瘍から剥離し, 腫瘍の内容物の一部を減量し た後に被膜外にて腫瘍を摘出した。摘出後, 腫 瘍の圧迫のため顔面神経の煩骨枝，頓筋枝の過 伸展が確認された。

病理組織所見：楕円形核を有する Spindle cell の，車軸状・柵状に配列した増生が認めら れ(図 3 ), Antoni A type の神経鞘腫と診断さ れた。

術後経過：術後 3 日目上り右顔面神経麻痺が 出現したが，およそ 3 力月後に麻痺は注ぼ完全

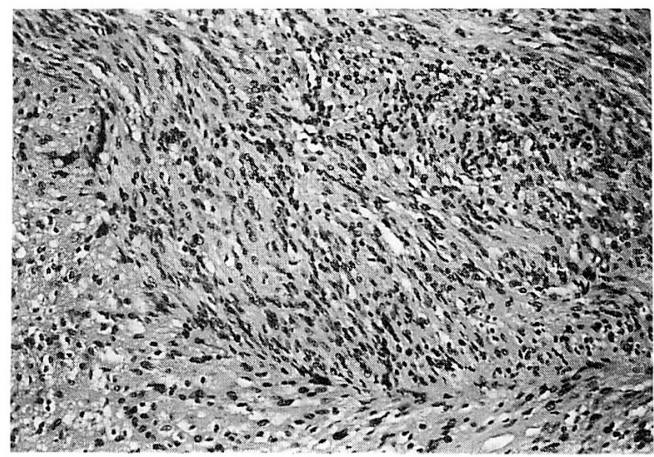

図 3 病理所見

楕円形の核を有する spindle cell の棚状増生が認 められ, Antoni A type の神経鞘腫と診断された。 
に回復した。

\section{考察}

神経鞘腫は神経鞘由来の良性腫瘍で, 文献上 schwannoma, neurinoma, neurilemmomaなど と呼ばれるが，これらは概念的に同一範疇に属 するものと考えられている。また，同じく Schwann 細胞に由来する神経線維腫とも本質 的には同一のものとされている.

その発生頻度は日野原 ${ }^{3}$ の本邦195例をまと めた報告によると，約半数が隹髄から，25\%が 小脳橋角部から，10\%が舌，胃腸管，縦隔洞， 四肢屈側，軀幹皮下に発生し，耳下腺由来のも のは 2 例にすぎない. 欧米での Das Gupta ${ }^{4)}$ の 頭頸部領域の136例の報告でも頸部が約半数を 占め, 耳下腺由来の神経鞘腫は10例之稀である.

一方, 耳下腺腫瘍中での神経鞘腫の頻度は, 表 1 のごとく，本邦，欧米の報告ともに低い. 本邦における耳下腺神経鞘腫の報告例は，われ われの涉诵し得た範囲では，本症例を含めて 32 例であり稀なものといえる。その詳細は表 2 お よび表 3 に示した.

1. 年秢：12歳から62歳までに分布し, 本症

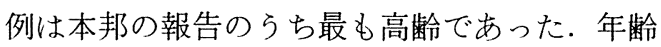
の記載のある 24 例の平均は 40.3 歳（男性38.0歳, 女性 41.1 藏）であった。本邦の耳下腺神経鞘腫
の好発年秢は40歳代といわれており，中年層に 多いといえる.

2. 性別：耳下腺良性腫瘍が女性に多いのと 同様に神経鞘腫においても男性：女性=約 1 : 3 で女性に多くなっている。これは，耳下腺内 神経鞘腫 6 例の 5 ち 例が女性であったといら Roos ら 43 の報告と一致している. なかでも特 に40歳代と50歳代の女性が約半数を占めている.

3. 初発症状：記載のあった25例中20例（80 \%）が耳下腺部およびその周囲の腫脹または腫 瘤を初発症状としており，顔面神経麻痺を初発 症状とした例は 3 例（12\%）に過ぎなかった。

4. 初診時の腫瘍の性状 : 記載のあった全て の症例で表面が平滑であり，癒着は18例中 1 例 （5.6\%）でみられた。これは他の耳下腺良性腫 瘍における癒着の頻度（加納8） $9.1 \%$, 寺倉 ${ }^{11)}$ $5.3 \%)$ と差異は認められなかった。自発痛, 圧痛は15例中 4 例 $(27 \%)$ で認められ, 他の耳 下腺良性腫瘍 (杉本 $\left.{ }^{7}\right) 5.1 \%$, 加納 $\left.{ }^{8}\right) 10.7 \%$, 寺 倉 ${ }^{11)} 5.3 \%$ ）に比べて高い頻度でみられた.

5. 来院までの期間：1 カ月から20年と幅広 く分布しているが, 総じて年単位の症例が多い. これは本腫瘍の発育が緩徐であり，耳下腺部腫 脹の他に臨床症状を呈するまでに長時間かかる ためであろらと考えられる。ささら，本症例の

表 1 報告例にみる耳下腺腫場中の神経鞘腫の頻度

\begin{tabular}{|c|c|c|c|c|c|c|c|}
\hline 北 & 村 & 5 & & $\left(\begin{array}{lll}197 & 9\end{array}\right)$ & 7 例 & 207 例 & $3.4 \%$ \\
\hline 村 & 上 & 8 & 1 & $(1976)$ & 0 例 & 70 例 & $0 \%$ \\
\hline 杉 & 本 & 7 & 1 & $\left(\begin{array}{llll}1 & 9 & 8 & 1\end{array}\right)$ & 1 例 & 83 例 & $1.2 \%$ \\
\hline 加 & & 8 & & $(1982)$ & 1 例 & 86 例 & $1.2 \%$ \\
\hline 有 & & 9 & & $\left(\begin{array}{lll}1982\end{array}\right)$ & 0 例 & 74 例 & $0 \%$ \\
\hline 金 & & 1 & (1) & $(1985)$ & 8 例 & 340 例 & $2.4 \%$ \\
\hline 寺 & 倉 & 1 & 11 & $(1988)$ & 1 例 & 117 例 & $0.85 \%$ \\
\hline 井 & & 1 & 21 & $(1989)$ & 0 例 & 211 例 & $0 \%$ \\
\hline \multicolumn{4}{|c|}{ Kirklin'3) } & $\left(\begin{array}{llll}1 & 9 & 5 & 1\end{array}\right)$ & 1 例 & 709 例 & $0.14 \%$ \\
\hline \multicolumn{4}{|c|}{ Eneroth ${ }^{1} \Delta$, } & $(1964)$ & 2 例 & 802 例 & $0.25 \%$ \\
\hline \multicolumn{4}{|c|}{ Ed d e y 151} & $\left(\begin{array}{lll}19 & 9 & 0\end{array}\right)$ & 1 例 & 138 例 & $0.72 \%$ \\
\hline \multicolumn{5}{|c|}{ Nus sbaum $161(1976)$} & 1 例 & 700 例 & $0.14 \%$ \\
\hline \multicolumn{5}{|c|}{ Sharkey $\left.{ }^{17}\right) \quad(1977)$} & 0 例 & 355 例 & $0 \%$ \\
\hline \multicolumn{5}{|c|}{$\mathrm{Balle} 181 \quad(1984)$} & 2 例 & 142 例 & $1.4 \%$ \\
\hline
\end{tabular}


ように来院後も自覚症状がないことから, 手術 に同意せず長時間放置している例も多くある.

6 . 顔面神経麻痺: $\mathrm{Bretlau}^{44)}$ は耳下腺内神 経鞘腫の $20 \%$ K, Kavanagh ${ }^{45}$ ) は 32 例中 8 例 （25\%）に顔面神経管麻㽻を認めたと報告して おり，本邦においても28例中 9 例 $(32 \%)$ に顔 面神経麻痺が認められた。しかしながら, 腫瘍 の位置が明らかな 7 例のらち 6 例までは腫瘍が
耳下腺内だけでなく顔面神経管垂直部にも存在 しており, 腫瘍が耳下腺内に限局した症例で顔 面神経麻痺を呈したものは16例中 1 例 (6.3\%) にすぎなかった。これは耳下腺の良性腫瘍にお ける顔面神経麻痺の頻度（杉本7) $6.8 \%$, 加納 ${ }^{8)}$ $3.6 \%$ ）に近い值である。このことから，腫瘍 の位置, 特に顔面神経管垂直部に腫瘍が存在す るか否かが顔面神経麻痺の出現に大きく関与し

表 2 本邦に捣ける耳下腺内神経鞘腫の報告例

\begin{tabular}{|c|c|c|c|c|c|c|c|c|c|c|c|c|c|c|c|}
\hline No. & 報告者 & 年 & 年秢 & 性 & 初発症状 & $\begin{array}{l}\text { 腫瘍 } \\
\text { 表面㟲 }\end{array}$ & 盖 & 状 & 顔面 & $\begin{array}{l}\text { 来 } \text { 院 } \\
\text { 玉での } \\
\text { 期 } \\
\text { 間 }\end{array}$ & 部位 & 多発性 & $\mid$\begin{tabular}{|c|} 
顔面神経 \\
華直 部 \\
との合併
\end{tabular} & $\begin{array}{l}\text { 術後 } \\
\text { 痺 }\end{array}$ & 発生母地 \\
\hline 1 & 米 倉1) & 1962 & & & & & & & & & & & & & 須面神経 \\
\hline 2 & 北 村19) & 1963 & 36 & $\mathrm{f}$ & 耳下腺部腫脹 & & & & - & & 右 & & & - & \\
\hline 3 & 梅 田 ${ }^{20)}$ & 1965 & 42 & $\mathrm{f}$ & 外耳道月 & & & & + & 10年 & 右 & & + & & \\
\hline 4 & 小 倉 ${ }^{21)}$ & 1966 & & & & & & & + & & 右 & & & + & \\
\hline 5 & 小 出22) & 1966 & 54 & $\mathrm{f}$ & 耳下腺部腫脹 & 平滑 & - & - & + & 8 年 & 左 & $+(5$ 個 $)$ & + & + & 顔面神縚 \\
\hline 6 & 梅 田 ${ }^{23)}$ & 1967 & 12 & f & & & & & & & & & & & \\
\hline 7 & 今 野24) & 1970 & 27 & $\mathrm{f}$ & 耳下腺部腫瘍 & 平滑 & - & 王痛 & - & 5 力月 & 左本幹 & & - & + & 顔面神経 \\
\hline 8 & 平 出 ${ }^{25)}$ & 1974 & 41 & $\mathrm{f}$ & 耳下腺部腫脹 & 平滑 & - & + & - & 1 力月 & 右深葉 & & & 一過性 & 不明 \\
\hline 9 & 北 村 26$)$ & 1975 & 14 & $\mathrm{f}$ & & & & & & & 深葉 & & & & 不明 \\
\hline 10 & 黄川田 ${ }^{27)}$ & 1977 & 45 & $\mathrm{f}$ & 口角攣縮 & & & & + & 6 力月 & 右本幹 & & + & & 顔面神経 \\
\hline 11 & 猿 田 ${ }^{28)}$ & 1) 1978 & & & & & & & - & & & & - & & 顔面神䊽 \\
\hline 12 & & 2)1978 & & & & & & & - & & & & - & & 顔面神経 \\
\hline 13 & 南 299 & 1980 & 34 & $\mathrm{~m}$ & 耳下腺部腫脹 & 平滑 & - & & - & 5 力月 & 右深葉 & & - & 一過性 & 不明 \\
\hline 14 & 杉 本7) & 1981 & 50 代 & $f$ & & & & & & & & & & & \\
\hline 15 & 加＼cjkstart納8) & 1)1982 & & & & & + & - & + & & & & & & \\
\hline 16 & & 2)1982 & & & & & - & - & - & & & & & & \\
\hline 17 & 古 川30) & 1983 & 42 & $\mathrm{~m}$ & 耳下腺 & 平滑 & - & - & - & 6 力月 & 左 & +(3個) & - & - & 顔面神経 \\
\hline 18 & 宮 原 ${ }^{31}$ & 1984 & 40 & $\mathrm{~m}$ & 耳下腺部腫瘤 & 平滑 & - & - & - & 20年 & 右浅葉 & & - & - & 不明 \\
\hline 19 & 竹生田 ${ }^{32)}$ & 1984 & 43 & $\mathrm{f}$ & 耳前部腫瘤 & 平滑 & - & + & - & 9 年 & 左両葉 & $+(4$ 個 $)$ & - & + & 顔面神経 \\
\hline 20 & 湯 本 ${ }^{32)}$ & 1984 & 59 & $\mathrm{f}$ & 耳下腺部腫脹 & 平滑 & & & + & 4 年 & 右深葉 & & + & & 顔面神経 \\
\hline 21 & 高 岡 ${ }^{34)}$ & 1984 & 27 & $\mathrm{f}$ & 顔面神経麻痺 & 平滑 & - & & + & 1年7カ月 & 右深葉 & & - & & 顔面神経 \\
\hline 22 & 永 井 ${ }^{35)}$ & 1985 & 39 & f & 耳下部腫瘤 & & - & + & - & 10年 & 右深葉 & & - & + & 顔面神経 \\
\hline 23 & 池 田 36 ) & 1985 & 44 & $\mathrm{f}$ & 耳下腺部腫脹 & 平滑 & & - & - & 3 年 & 左深葉 & & - & & 顔面神経 \\
\hline 24 & 古 家 ${ }^{37)}$ & 1986 & 59 & $\mathrm{f}$ & 耳下腺部腫瘤 & 平滑 & & & $(+)$ & 13年 & 右 & + (4個) & + & + & 顔面神経 \\
\hline 25 & 後 藤38) & 1987 & 45 & $\mathrm{f}$ & 耳下腺部腫瘤 & & - & - & - & 3 年 & 左本幹 & & - & + & 顔面神経 \\
\hline 26 & 長 山年) & 1987 & 14 & $\mathrm{~m}$ & 顔面神経麻瘦 & & & & + & 4 年 & 右本幹 & & + & + & 顔面神経 \\
\hline 27 & 岡 田40) & 1987 & 44 & f & 耳下腺部腫瘤 & 平滑 & - & & - & 7 力月 & 左本幹 & & - & + & 顔面神経 \\
\hline 28 & 小 島41) & 1)1988 & 39 & $\mathrm{~m}$ & 耳下腺部腫脹 & 平滑 & - & - & - & 1年2力月 & 右深葉 & & - & + & 顔面神経 \\
\hline 29 & & 2)1988 & 47 & f & 耳下腺部腫脹 & 平滑 & - & - & - & 4 力月 & 右本幹 & & - & + & 顔面神経 \\
\hline 30 & 関４2) & 1988 & 59 & $\mathrm{~m}$ & 耳下腺部腫脹 & 平滑 & - & - & - & & 左深葉 & & - & + & 顔面神絟 \\
\hline 31 & 寺 倉 ${ }^{11)}$ & 1988 & & & & & - & & - & & & & & & \\
\hline 32 & 本症例 & 1990 & 62 & f & 耳下腺部腫脹 & 平滑 & - & - & - & 3 力月 & 右深葉 & & - & 一過性 & 不明 \\
\hline
\end{tabular}


ているものと考えられる，本症例の場合にも腫 瘍は耳下腺内に限局しており, 顔面神経麻痺は みられなかった。

7. その他：左右差は右：左 $=14: 7$ と右に 多い傾向がみられ，また，深葉及び顔面神経本 幹にあるものが多い上らであった。 また多発例 は 4 例であった.

8. 起源神経：本邦の報告で起源神経を顔面 神経とした報告は24例中20例に達するが，その 判断については明確な基準がないのが現状であ る.耳下腺には知覚神経の他, 顔面神経, 自律 神経が存在しそのいずれもが神経䩗腫の起源神 経となりらる。しかしながら，耳下腺神経鞘腫 は解剖学的関係より, かつ, Schwann 䩗を例 外なく随伴しているといら事実より，その大部 分が耳下腺内を走行する顔面神経由来であろら と推測され, 腫瘍摘出にあたって, 顔面神経と 腫瘍に関係のないことが確認されていても摘出 部位から考えて顔面神経由来の腫瘍と推測する のが一般的であるという25)。 また，知覚神経， 自律神経に由来することが確認されたという報 告はない，本症例の場合は，紙状に過伸展され た神経が腫瘍表面を放射状に走行していたが両 者の間に明らかな瘉着はなく, 顔面神経との関 係は不明であった。

9. 診断：本邦において術前診断が正しくな されたといら報告は 1 例もみられなかったが， 欧米で術前診断が正しくなされた症例を Bretlau $^{44)}$ は52例中 4 例, Conley ${ }^{46)}$ は17例中 3 例報告している。このうち各々 1 例は吸引細胞
診によって術前診断がなされているが，本邦例 では吸引細胞診が行われた症例はみられなかっ た. 従来, 本腫瘍に特徵とされている顔面神経 麻痺は, 今回, 顔面神経管垂直部に腫瘍が存在 しない場合には頻度的に他の良性腫瘍と差のな いことが判明した．他の良性腫瘍に比べ頻度の 高かった疼痛の出現も診断価值としては低いと いわれている25)。現在のところ診断は組織診断 によらざるを得ない。

10. 治療：本腫瘍が限局性, 単発性の良性腫 瘍で放射線, 化学療法に反応し難いことから治 療は手術による摘出が原則である. 術後に顔面 神経麻痺を残した症例は18例中12例であり，一 過性の麻疩は 3 例にみられた。術後麻痺を防止 するために，顔面神経の走行に細心の注意を払 い，損傷を避けることが必要となるが，瘉着が 著しかったり腫瘍が神経を包みこんでいる場合 には切断を余儀なくされることがある．との際， 顔面神経の機能を保存するために, 切断した神 経の端々吻合や大耳介神経などの移植が行われ

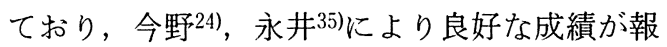
告されている.

\section{まとめ}

耳下腺に発症した62歳女性の神経鞘腫を報告 した. 右耳下腺部膨脹を主訴とし, 初診時に顔 面神経麻㽻は認められなかった。手術にて右耳 下腺深葉の腫瘍を摘出した。病理診断は神経鞘 腫であった。 また，本邦に拈ける耳下腺内神経 䩗腫の報告32例について検討を加えた.

表 3 本邦報告例の年龄別, 性別分布

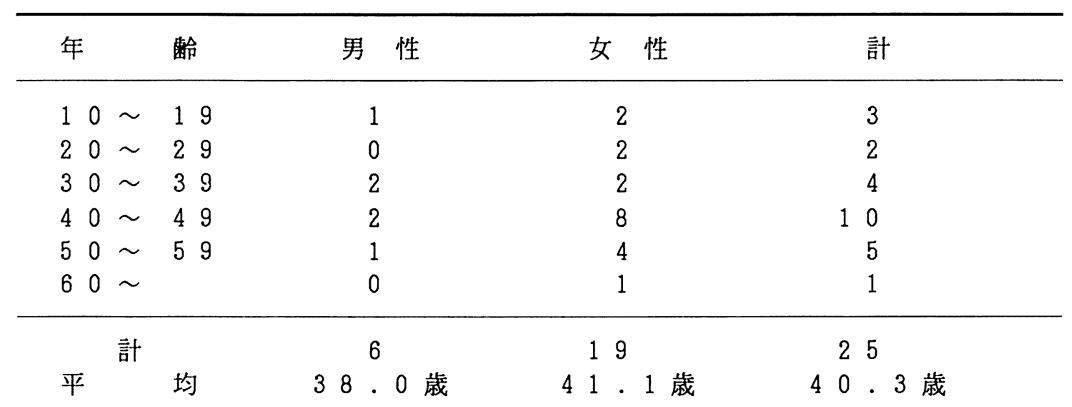


本論文の一部は第46回日耳鼻福島県地方部会にお いてロ演した。

\section{参考文献}

1）米倉英明，白木哲朗：耳下腺部腫瘍 2 例. 日耳 嶴 $65: 613,1962$.

2）赤崎兼義 : 病理学総論. 468 469頁, 南山堂, 東京, 1981 .

3）日野原正，宮下賢次，吉見充徳：耳鼻咽喉科領 域の神経䩪腫について.耳展 $13: 11 \sim 17,1970$.

4) Das Guputa TK, Brasfield RD, Storong EW, et al : Benign silitary schwannomas. Cancer 24 : 355〜366, 1969.

5）北村 武, 金子敏郎, 戸川 清, 他 : 耳下腺腫 瘍の臨床一教室20年間の統計的観察一.耳鼻臨 床 $64: 1286 \sim 1301,1971$.

6）村上 泰, 猪 忠彦, 堀内正敏, 他：耳下腺腫 瘍70症例の治療経験.耳喉 $48: 589 \sim 602,1976$.

7）杉本嘉朗, 平川勝洋, 夜陣紘治, 他 : 耳下腺腫 疸の統計的観察一当教室過去13年間の集計.耳 鼻臨床 $74: 2096 \sim 2103,1981$.

8）加納直行, 牧本一男, 藤村英一, 他 : 過去10年 間にお㹁る耳下腺腫瘍の統計。耳鼻臨床 75 : 1657 1666, 1982.

9）有馬敏夫, 中島恒彦, 朝郎真一郎, 他 : 当教室 における過去10年間の耳下腺腫瘍の臨床統計.

耳鼻 28 : 425〜429, 1982.

10）金子敏郎：耳下腺腫脹とその臨床一教室統計を 中心として一. 耳鼻 $24: 885 \sim 890,1978$.

11）寺倉直明, 田中克彦, 吉村 理, 他：耳下腺腫 瘍の臨床統計一当教室10年間の集計.耳鼾 34 : 698 702, 1988.

12）井上俊哉, 山下敏夫, 辻川覚志, 他 : 当教室 10 年間における耳下腺腫瘤の統計.耳鼻臨床 82 : 245〜250, 1989.

13) Kirklin JW, McDonald JR, Harrington SW, et al : Parotid tumors; Histopathology, clinical behavior and end results. Surg Gynecol Obstet $92: 721 \sim 733,1951$.

14) Eneroth $\mathrm{CM}$ : Histological and clinical aspects of parotid tumors. Acta otol Suppl 191: 1 99, 1964.

15) Eddey $\mathrm{HH}:$ Parotid tumors a review of 138 cases. Aust N Z J Surg 40 : 1 14, 1970.
16) Nussbaum M, Cho HT and Son ML : Parotid space Tumors of Non-salivary Origin. Ann Surg $183: 10 \sim 12,1976$.

17) Sharkey FE : Systemic evaluation of the World Health Organization classification of salivary gland tumors. Am J Clin Pathol 67 : 272 278, 1977.

18) Balle VH and Greisen $O$ : Neurilemmomas of the facial nerve presenting as parotid tumors. Ann Otol Rhinol Laryngol 93 : 70 72, 1984.

19）北村武, 武宮三三, 佐藤俊一：耳下腺 Neurilemmoma. 日耳鼻 $66: 1588,1963$.

20）梅田良三, 中橋常雄, 宮崎為夫 : 耳下部にみら れたノイリノーム症例. 日耳鼻 $68: 1158,1965$.

21）小倉義郎, 安原皓三, 小野田元男：耳下腺腫瘍 摘出症例. 日耳鼻 $69: 2117,1966$.

22) Koide $Y$, Takahashi $H$ and Arai $T$ : A cases of multiple neurinoma of the facial nerve. Larygoscope $76: 407 \sim 417,1966$.

23）梅田良三，小西武彦，石政喜弘，他：最近わが 領域で経験した神経鞘腫の数例. 日耳鼻 70 ： 865, 1967.

24）今野昭義, 北村 武, 戸川 清, 他 : 顔面神経 原発神経鞘腫の臨床的観察一 4 例の観察. 日耳 鼻 $73: 379 \sim 388,1970$.

25）平出文久, 野村恭也, 森田守：耳下腺ノイリ ノームの一症例. 耳鼻 $20: 506 \sim 510,1974$.

26）北村溥之, 宮本和雄, 岸本誠司, 他：耳鼻咽喉 科領域の神経鞘腫 5 例. 日耳鼻 $79: 1044,1976$.

27）黄川田 徹, 小林武夫, 野村恭也, 他 : 顔面神 経 Neuroma-3 症例の報告. 耳喉 $77: 899$ 906, 1977.

28）猿田敏行, 内藤準哉, 藤田洋祐, 他 : 顔面神経 鞘腫の 3 症例. 日耳鼻 $81: 288,1978$.

29）南吉文, 平田秀登, 小田 澄, 他: 耳下腺, イリノームの 1 症例. 耳喉 $52: 605 \sim 608,1980$.

30）古川仞, 井本浩二, 石黒英世, 他 : 顔面神経 由来耳下腺内顔面神経鞘腫の一例. 耳展 26 : 393 396, 1983.

31）宮原 裕, 佐藤武男：耳下腺 Neurilemmoma の一症例. 耳展 $27: 407 \sim 410,1984$.

32）竹生田勝次, 西嶌 渡, 寺邑公子: 耳下腺内顔 面神経より生じた多発性神経鞘腫の一症例.耳 喉 56 : 49〜 52, 1984. 
33）湯本英二，柳原尚明，丘村 熙: 顔面神経鞘腫 9 例一臨床像を中心に。耳鼻臨床77：1103〜 1109, 1984.

34）高岡基雄, 鈴木健男, 稲賀 潔, 他 : 顔面神経 由来と思われた耳下腺 Neurinoma の一例. 耳 鼻 $30: 373 \sim 377,1984$.

35）永井みどり，林 明俊，東野哲也，他：耳下腺 内に発生した顔面神経鞘腫症例. Facial N Res Jpn 5 : 153 156, 1985.

36）池田直也，二宮半三，近藤豊一，他 : 耳下腺部 に発生した巨大な神経鞘腫の一例. 霜放 25 : $301 \sim 306,1985$.

37）古家隆雄, 高原哲夫, 藤谷哲三, 他 : 多発性顔 面神経鞘腫の一症例. Facial N Res Jpn 6 : 109 $\sim 112,1986$.

38）後藤和彦, 岡田益明, 佐々木良二, 他 : 耳下腺 内顔面神経鞘腫の一例. Facial N Res Jpn 7 : 123 126, 1987.

39）長山郁夫, 嘉藤秀章, 岡部陽三, 他 : 当教室に おける過去13年間の神経鞘腫例について．耳展 $30: 47 \sim 53,1987$.

40）岡田智幸, 岩沢 寛, 高橋馨子, 他：顔面神経 鞘腫の二例. 耳鼻臨床 補 $9: 85 \sim 95,1987$.
41）小島 正, 志藤文明, 三部重雄 : 耳下腺内顔面 神経䩵腫の 2 例. 耳展 $31: 45 \sim 51,1988$.

42）関 哲郎, 今井 透, 金子省三, 他 : 耳下腺部 顔面神経由来の神経原性腫瘍, 耳展 31：471 481, 1988.

43) Roos DB, Byards LT and Ackerman LV : Neurilemmomas of the facial nerve presenting parotid gland tumors. Ann Surg 144 : 258 262, 1956.

44) Bretlau P, Melchiors $H$ and Krogdahl A : Intraparotid neurilemmoma. Acta Otolaryngol $95: 382 \sim 384,1983$.

45) Kavanagh KT and Panje WR : Neurogenic Neoplasms of the Seventh Cranial Nerve Presenting as a Parotid Mass. Am J Otolaryngol $3: 53 \sim 56,1982$.

46) Conley J and Janecka I : Neurilemmoma of the facial nerve. Plast Reconstr Surg 52 : 55 60, 1973.

$$
\left(\begin{array}{l}
\text { 別刷請求先 : 渡邉 睦 } \\
\text { 厂960-12 福島市光が丘 } 1 \\
\text { 福島県立医科大学耳鼻咽喉科学教室 }
\end{array}\right)
$$

